\title{
The Power of Women in Indonesian Political Election as A Study of Critical Discourse Analysis
}

\author{
Vidya Mandarani ${ }^{1}$ \\ \{vmandarani@umsida.ac.id $\left.{ }^{1}\right\}$ \\ Universitas Muhammadiyah Sidoarjo, Indonesia ${ }^{1}$
}

\begin{abstract}
This research concerned with the news related to women's representation in political election. Theory of critical discourse analysis used popularized by Sara Mills to investigate media bias in coverage of women as well as to display an actor as a subject, which defines an event or group in political events in Indonesia, specifically in East Java. The research used content analysis in qualitative research design. The data are taken from the news of Jakarta Post E-paper entitled "challenges, opportunities for new women leaders". The findings revealed the existence of exposure against both women powerfulness and powerlessness in political election. The result represented the woman as a side who has the same effort to compete in political contest. This research is expected to contribute to the strength analysis of a media in lifting women into winners in political elections.
\end{abstract}

Keywords: Critical Discourse Analysis, Political Election, Women.

\section{Introduction}

Media is one weapon for political figures to form discourse. Discourse that is formed by the news in one with the other media can have different perspectives. This is caused some media cannot contain neutral news. Media tends to lead readers to understand a discourse based on the news presented. In an election event, the role of the media were extraordinary in presenting the character's discourse during election. In Indonesia today, women are running for office as governors or regional heads. The power of media to raise women in the news is very interesting to be explored. Previous research investigated gender stereotypes at political media discourse using CDA. Stereotypes in politics are reproduced and generated through language used in media. They have suggested that well-organized and structured CDA can reduce bias in interpreting the data [1]. This research would be able to better convince the reader of their claims regarding how gender stereotypes in politics are reproduced and generated through language used in news media. In the analysis model, Sara Mills concerns at how actor positions are displayed in the text. These positions in the sense of who is the subject of the story and who is being the telling object will determine how the structure of the text and how the meaning is applied in overall text [2]. Further, how readers and writers are displayed in the text as presented as follows [3]. First of all, Subject-Object Position; analysing how actor positions in the text are widely displayed how the ideology and dominant beliefs from the text. Position as the subject or object in the representation includes certain ideological content. Second, Position of Readers (Listeners); the text becomes negotiations result between writers of news (media) and readers of the news (listeners). In case, the position of reader is 
crucial thing to be considered [4]. Third, Media Position; it is not only a free channel but also a subject that constructs reality, complete with views, biases and alignments. Media is seen as a social construction agent that defines reality accordingly with its interests. It is not a neutral means but rather have partiality to certain things. In the media, the ideology adopted will determine whether it is good or bad to be established for public. Therefore, ideology is one of the important factor for the media in determining direction of the program.

In addition, ideology as a system of beliefs shared socially by the actors involved. It certainly refers to the existence of collective beliefs that must be understood as early stages in understanding ideology. Ideology is not only a social belief, but a fundamental or axiomatic character of social depiction of a social group, through certain social and mental (sociocognitive) behaviors [5][6]. As in the East Java governor election process which consists of 2 candidates, one of them is a female candidate, namely Khofifah Indar Parawangsa who is paired with Emil Dardak.

\section{Methodology}

This qualitative research applies critical discourse analysis by Sara Mills. Content analysis has been described as a family of analytical approaches from 'impressionistic, intuitive and interpretative analyses to strict textual analysis'. Kind of content analysis is used depending on the research field of the researcher [7]. The real activity of content analysis is to make classification of word units representing similar meaning. Content analysis is same to text analysis, where we will focus on analysing text along with contect and wider range of semantic. Analysis unit, in this research, is the news of Jakarta Post E-paper with title Challenges, Opportunities for New Women Leaders, uploaded on July, 18, 2018 [8]. The data were collected by accessing and downloading the news texts. News texts then were observed and analyzed by Sara Mills' CDA.

\section{Results and Discussion}

The discussion of this study includes three things, namely subject-object position, and representation of women in patriarchal perspective.

\subsection{Subject-Object Position}

The title of the news is intriguing considering how the author emphasized word "opportunities", in portraying the chances and challenges for the observed news' object (female politic cadres) in competing within the patriarchal domain of political election; and phrase "new women leaders" as well, in representing the condition of female leader scarceness.

And then, the news started by author' perception towards females' probabilities of political electability in partaking into the governor contestation, in which is represented by Khofifah's effort in nominating herself for the third run at the regional election that surprisingly worked out quite well, compared to her previous first and second attempt. Following the opening, the news also mentioned a status quo regarding with the males' political proportion superiority, which is predominantly established within this patriarchal 
societal culture, by highlighting the small ratio of woman participatory in every local/regional governmental event.

The quick count results of the 2018 regional head elections by survey institutes show a positive trend in women's electability. Two other women are set to become deputy governors: Chusnunia Chalim in Lampung, South Sumatra, and Siti Rohmi Djalilah in West Nusa Tenggara. Women will lead the regencies of Lebak in Banten, Bogor and Purwakarta in West Java, Jombang and Probolinggo in East Java, Tegal in Central Java, Mempawah in West Kalimantan and Rote Ndao in East Nusa Tenggara, while female mayors will lead Banjar in West Java, Mojokerto in East Java and Kotambagu, North Sulawesi. Since the first direct elections for regional heads in 2005 , the number of women candidates has slightly increased.

The news closed by supporting women to be part of governmental position as next leaders in order to create a valuable and obliged governance with gender-equate environment. Theoretically, it depicts women as the sole object since there is no clear comparison between male and female. However, it is probably stated as well that subject or object position is not available for both genders, because no male's specific name is ever mentioned within the text. For example:

The main objective in the struggle to increase the number of women in public positions is to influence decision making and budget formulation to become fairer and to empower marginal groups, particularly women.

Data above have shown that the woman as a person who has the same effort to compete in political contest. In a few excerpts of the choice of words, phrases and sentences indicate that there is a balance between subject and object position. Women began to be given a portion and recognized their ability to lead. The following are some data views relating to the strengths and weaknesses of women in politics from patriarchal perspective.

\subsection{Representation of Women in Patriarchal Perspective}

\section{A Strong, Capable and Faithful Woman}

This text represented the woman as a person who has the same effort to compete in political contest. It is proven from the following line:

Nevertheless, opportunities for women regional heads to perform beyond expectations are wide open. Note the declining resistance to women leadership, as demonstrated by the women who secured victories in deeply patriarchal areas, though indeed several were related to ruling elites. Khofifah also has a strong Islamic base in East Java.

However, the sentences above showed that woman can perform beyond expectations are wide open. This research indicated that there is data that highlights the woman within the news text. It is seen in the line below:

The main challenge of any new executive is building clean local governance, obviously by not engaging in any action bordering on graft; women seem to carry more expectations regarding this than men.

From the example of the news sentence above, the news represent the power of women in the political field. In the same news. In the Jakarta news, this post was not only to convey the power side of women, but also to the weakness of women in political reporting. 


\section{Powerlessness of Woman}

Woman is represented as a person who has less power compared to men for contributing in governmental business, specifically regional election. It is showed from the sentence below:

First, like any other candidacy under today's electoral system, which is highly dependent on political parties, a woman's candidacy is highly related with political parties' interest to wrest power at the local level.

In addition, the following sentence also presented that woman leader is highly preferred her own voters with the same gender, in which author described as 'kinship' as follow:

Once elected, women apparently nominated for their kinship with local elites may face the strongest pressure to resist corruption — as reflected in the many women arrested and tried for graft.

In line with the previous notion, the author did mention the inability as well as the lack of self-governing act of woman who has entangled within politic of familial dynasty that is prescribed in the following sentence:

as reflected in the many women arrested and tried for graft. Thus the nomination of wives or daughters of incumbents indicate attempts to maintain family control over political and economic resources.

The Jakarta Post presented news with 2 perceptions regarding women's strengths and weaknesses to provide readers with an understanding of gender differences in political news. On top of that, Sara Mills' model is appropriate to asses text allignment of two on-line texts. Previous research tried to find possibility of two news from critical discourse analysis of Sara Mills at the feminism perspective, and the implied power relations in the text [9]. The findings are similar with this research that the news tend to represent woman dominance. Seen from the choice of word, woman has balanced position within the texts. She does not only take the subject position, but also the object position.

To be compared with a research about Discourse of Online Media Coverage Holly's murder resulting different findings. In that research explained that the representation of women in the news on the murder of Holly in online media have represented women as powerless position. Also, it has placed women as object and men as subject [10]. However, for the news text used in this research is one of politics news that present the position of subject and object equally.

\section{Conclusion}

To sum up, news media give so much influence in shaping public opinion. Specially the news about Challenges, opportunities for new women leaders, in Jakarta Post E-Paper, uploaded on July, 18, 2018 depicts women as the sole object but still there is women powerlessness and gender position in political election. The results also represents the woman has the same effort to compete in political contest in Indonesia. Micro features used shows woman was positioned proportionally within texts. Woman does not only take the subject position but also the object position.

Acknowledgement. I proudly present all my gratitude to Universitas Muhammadiyah Sidoarjo for giving me chance to join the International Seminar to publish this article. 


\section{References}

[1] Sriwimon, L., Zilli P.J.: Applying Critical Discourse Analysis as A Conceptual Framework for Investigating Gender Stereotypes in Political Media Discourse. Kasetsart Journal of Social Sciences. Vol. 38, pp. 136-142 (2017)

[2] Eriyanto: Analisis Wacana: Pengantar Analisis Teks Media. LKis, Yogyakarta (2001)

[3] Mills, S.: Knowing Your Place: A Marxist Feminist Stylistic Analysis. Michael Toolan (ed.) Language, Text and Context: Essays in Stylistics. Routledge, New York (1992)

[4] Mills, S.: Discourse (The New Critical Idiom). Routledge, New York (2004)

[5] Van Dijk, Teun A.: Text and Context (Exploration in the Semantics and Pragmatics of Discourse). Longman, New York (2014)

[6] Badara, A.: Analisis Wacana: Teori, Metode dan Penerapannya pada Wacana Media (Edisi 1). Kencana. Jakarta (2012)

[7] Rosengren, K.E..: Advances in Scandinavia Content Analysis: An Introduction. SAGE. pp. 9-19 (1981)

[8] Wardani, S.B.E.: Challenges, Opportunities for New Women Leaders. The Jakarta Post E-paper. http://www.thejakartapost.com/academia/2018/07/18/challengesopportunities-for-new-women-leaders.html

[9] Sukaesih, L., Brida L.: Assessing Text Allignment: Sara Mills' Model. Epigram. Vol. 14, No. 1, pp. 83-88 (2017)

[10]Zaini, N.: The Discourse of Online Media Coverage on the Holly's Murder: Wacana Liputan Media Online tentang Pembunuhan Holly. IPTEK-KOM. Vol. 17, No. 1, pp. 87-98 (2015) 